\title{
THE INTERACTION OF WORKING CAPITAL MANAGEMENT AND PROFITABILITY MEASURES
}

İlker YILMAZ

\begin{abstract}
In this article, the interaction between working capital management success and different measures of profitability was examined. When components of net working capital are kept at optimal levels, this situation benefits company to use resources more efficiently and helps profitability. Similarly, high levels of profitability helps avoiding idle working capital practices. By using a sample consisting of 172 non-financial companies traded Borsa Istanbul (BIST) in Turkey, and 5-year data covering 2009-2013, regressions were run to analyze how profitability affects working capital management which is measured in terms of Cash Conversion Cycle (CCC) and also how CCC affects profitability measures. Most of the alternative cases tested have given significant results. Decreasing CCC affect positively profitability measures. Similarly, improved level of profitability helps a better working capital management and affects inventory turnover, receivables collection and payable deferral. Although long-term financial decisions and policies have an important role in the sustainability and profitability of the companies, short-term financial management and working capital management which is the most important policy in this sense can also have a profound effect on the company success.
\end{abstract}

Keywords: Working capital, profitability, liquidity

Jel Codes: G30, L25, C23

\section{İŞLETME SERMAYESİ YÖNETIMMİ VE KARLILIK GÖSTERGELERİ ARASINDAKİ ETKİLEŞIM}

\section{Öz}

Bu çalışmada, işletme sermayesi yönetiminin başarısı ile farklı karlılık göstergeleri arasındaki karşılıklı ilişkiler ve etkileşim incelenmiştir. İşletme sermayesinin bileşenleri optimum seviyelerde tutulduğunda, bu durum kaynaklarını daha etkin ve verimli kullanmasını sağlar ve karlılı̆̆ üzerinde olumlu bir etkiye yol açar.

* $\quad$ Assistant Professor of Finance at Nişantaşı University of Turkey, ilker.yilmaz@nisantasi.edu.tr 
Benzer şekilde, yüksek karlılık göstergeleri atıl işletme sermayesi uygulamalarından kaçınmaya yardımcı olur. Hisseleri Borsa İstanbul'da (BIST) işlem gören 172 reel sektör (finans-dışı) firmasının, 2009-2013 yılları arasındaki 5 yıllık verilerini kullanarak, çeşitli panel data regresyon analizleri gerçekleştirildi. Karlılığın işletme sermayesi yönetimini nasıl etkilediği, aynı zamanda işletme sermayesinin karlılı̆̆ nasıl etkilediği analiz edildi. İşletme sermayesi yönetiminin temel göstergesi nakit çevrim döngüsüdür. Test alternatiflerinin çoğu anlamlı sonuçlar vermiştir. Nakit çevrim döngüsünün kısaltılması karlılık göstergelerini olumlu etkilemektedir. Aynı zamanda, karlılık göstergelerindeki iyileşme işletme sermayesi yönetimini olumlu etkilemekte; stok devir hızı, alacak tahsi süresi ve borç ödeme süresi göstergelerini iyileştirmektedir. Uzun vadeli finansal kararlar ve politikalar şirketlerin sürdürülebilirliği ve karlılığı üzerinde önemli bir role sahip olmasına rağmen, kısa vadeli finansal yönetim ve bunun en önemli aracı olan işletme sermayesi yönetimi de şirketi başarısı üzerinde çok önemli bir yere sahiptir.

Anahtar Kelimeler: İşletme sermayesi, karlılık, likidite

Jel Kodları: G30, L25, C23

\section{Introduction}

One of the fundamental assumptions in finance literature is that the objective and responsibility of the finance manager is to maximize wealth of shareholders. Also it is known that the way to maximize wealth of shareholders is to maximize share price. In company and stock valuation, it is generally accepted that the value is derived from the future cash flows generated by the company. Therefore, primary objective of the finance manager is directly related to cash generation ability of the company. In this context, cash generation ability is dependent on two important concepts; profitability and liquidity. In the long run, there are several decisions finance manager makes in order to determine long term sustainability of the company, for instance, capital budgeting decisions and capital structure decisions. However, besides those long-term decisions, the finance manager must also actively manage and decide about working capital policies. Working capital policy is generally refer to the management of both current assets and current liabilities, although the more technical concept covering both groups is net working capital, which is the difference between current assets and current liabilities.

Working capital management and its relation to profitability of the company is important for the long term sustainability. This relationship and its direction has been studied and some researchers assumed that liquidity is the first importance for the finance manager, whereas some others attach more importance to profitability. It is commonly agreed that there is a trade-off between liquidity and profitability. The level of working capital items and the success of company in managing them affect both liquidity and profitability. 


\section{Literature Review}

\section{I.I Working Capital Management}

There have been several studies about working capital management; some of which searched for the relationship of working capital management and profitability while others searched for its relation with firm value.

The objective of working capital management is to sustain and survive the firm by performing its daily operations and to be able to meet short term obligations. There is a trade-off between profitability and liquidity when we talk about the objective of working capital and level of the items comprising it. The trade-off between liquidity and profitability was stated by Smith (1980,p.549) firstly. At the same time, both liquidity and profitability cannot be targeted. Efforts to increase profitability lessen liquidity, and similarly efforts to maintain and increase level of liquidity may harm profitability.

Working capital management includes three components; accounts receivable, inventory, and accounts payable. For all those components, managers are faced a trade-off.

According to Wang (2002,p.162), if a firm reduces inventory days too much, it may lose sales because of stockouts and if the firm reduces receivable days too much, it may lose some customers who demand trade credit. As for payables, reducing deferral period too much may cause losing of some early payment discounts.

Garcia-Teruel and Martinez-Solano (2007,p.166) stated that firms face two net working capital strategies; to minimize working capital investment or to adopt strategies designed to increase sales. They pointed out the management's trade-off between expected profitability and risk for the optimal level of working capital investment.

Having stated that different businesses may have different working capital requirements, Ukaegbu (2014,p.2) emphasized that by granting trade credit to the customers, firms may focus sales increases and such an action may result in higher stock turnover, but this may cause cash flow problems when receivable days get longer.

\section{I.2 The Importance of Working Capital Management}

The firms may adopt one of three approaches of working capital management. Conservative approach requires the use of long-term capital to finance all the permanent assets and to meet seasonal needs and the firm uses a small amount of short-term capital. In moderate approach which is also known as maturity matching approach fixed assets and permanent current assets are financed with long-term debt and temporary current assets are financed with short-term debt. Lastly, in aggressive approach, the firm finances some of the permanent assets with short-term debt. (Brigham and Houston, 2009,p.492)

In order to analyze efficiency and effects of working capital management, it must be measured. The most important tool to measure working capital management is the cash conversion cycle (CCC) which is firstly introduced by Gitman (1974,p.81). Richards and Laughlin (1980,p.34) 
defines CCC as the net time interval between the cash purchases for resources and cash receipts from customers. The CCC describes the business cycle in terms of days; that is, it is the total number of days between purchase of raw materials and receipt of cash from customers as a result of sales. It includes three items: average collection period, inventory turnover days, and payment deferral period. The aim of CCC management has two dimensions; to get cash flows as quickly as possible and to postpone cash outflows as late as possible. When succeeded, both dimensions result in a shorter cash conversion cycle. (Soenen,1993, p.53).

CCC measures the efficiency of working capital because of the fact that it reflects how quickly current assets are converted into cash. If a firm invests more in working capital than needed, this may increase costs and decrease competitiveness and this situation is also related to alternative capital structures. (Öhman,2014,p.443).

CCC is a measure which is in terms of days and it does not take into account the monetary amounts. As a solution of this situation, Gentry et al.(1990,p.90) proposed a new concept as weighted cash conversion cycle (wccc). WCCC calculates the timing by the monetary amounts of each component of the cycle. The weight of each component is calculated by the dividing the cash amount tied up by the final value of the component.

Another measure used to analyze WCM is the net trade cycle (NTC) which is the expression of CCC as a percentage of sales. NTC is proposed by Shin and Soenen (1998,p.38) due to the weaknesses of CCC and WCCC. NTC is an indicator of how many "days sales" the company has to finance its working capital and it is also an estimate of additional fund needed for working capital which is stated as a percentage of projected sales growth. By using the NTC, they found a negative association between working capital and profitability.

\section{I.3 The Relationship Between Working Capital Management and Profitability}

Jose et al. (1996,p.35) pointed out that more aggressive liquidity management which means also lower CCC leads to higher levels of profitability.

Deloof (2003,p.585) concluded in his paper that since the firms have a large investment in working capital, the success of this investment's management has a direct and important effect on the profitability of firms. He found a significant negative relation between the profitability measure (gross operating income) and the components of cash conversion cycle.

Similarly, Lazaridis and Tryfonidis (2006,p.31) found a negative relationship between profitability and the cash conversion cycle. Having observed that lower gross operating profit is associated with an increase in payable deferral period, they concluded that less profitable firms wait longer to pay their bills and those firms enjoy the credit period granted by the suppliers. They reached similar conclusion for accounts receivable and inventory.

By using return on assets (ROA) as the profitability measure, Padachi (2006,p.45) analyzed the effect of working capital management on profitability and its trend. The results of the study revealed that higher levels of investment in receivables and inventory lead to decreases in profitability. 
Garcia-Teruel and Martinez-Solano (2007,p.175) examined the case for small and mediumsized companies, because of the fact that current assets comprise an important percentage at their balance sheets. They found a significant negative relation between profitability and receivable days and inventory days.

Gill et al.(2010,p.8) examined the working capital management-profitability issue for US manufacturing firms. They reached two results. One of them is that there is a negative relationship between profitability and receivable days, and secondly, there is a positive relationship between cash conversion cycle and profitability. Depending on the results, they concluded that profitability can be enhanced by a more efficient working capital management.

Enqvist et al. (2014,p.48) pointed out that companies aim to achieve an optimal level of working capital and this level vary depending on business conditions. By taking business cycle effects, they concluded that there exists a negative relationship between CCC and profitability. Regarding the efficiency of working capital items, they reported that companies increase profitability by efficient inventory management, lower receivable days and shorter payable cycles. They also found that the impact of CCC on profitability is higher in economic downturns.

\section{Data And Methodology}

\section{I Data And Variables}

The sample used in this article includes non-financial companies from different industries. The reason to exclude financial companies, namely and most importantly the banks, is that those companies have a very distinct type of business and as a result of this situation, they have different financial statements. Although several industries within the real sector have also different practices, they possess common characteristics in terms of their financial statements. The data covers a 5-year period from 2009 to 2013 . The number of companies in the sample is 172 .

There are several financial ratios used to analyze the relationship between working capital management and profitability. The variables are defined as follows:

Cash conversion cycle (CCC) : It represents the time period between the purchase of inventories and the collection of receivables from the customers. It is formulated as; receivables days + inventory days - payables days.

Gross profit margin (GPM): It is the first level indicator of profitability. It is formulated as gross profit divided by sales. Gross profit is found by deducting only cost of goods sold from sales.

Return on assets (ROA): It represents the profitability of the assets. It is formulated as net income divided by total assets.

EBIT Margin (EBITM): It represents the profitability of the company based on its main operating business. It is formulated as Earnings Before Interest and Taxes divided by Net Sales.

Natural logarithm of Total Assets: This measure is used as a control variable, because data include the companies which are different in size. 


\subsection{Methodology}

Several regressions were run to explore the relationship between working capital management and profitability indicators. Data used in the study comprise both cross-sections and time-series, then panel data methods were used. Panel data is defined as a data set constructed from repeated cross sections over time. With a balanced panel, the same units appear in each time period. With an unbalanced panel, some units do not appear in each time period, often due to attrition. (Wooldridge, J.M 2002,p.430)

Statistical data analysis was performed by using Stata. For each alternative case mentioned above, panel regression with fixed effects and panel regression with random effects were run. According to test results, those regressions were compared in order to determine which model must be used. Hausman test is performed in order to decide between fixed and random effects. The model selected must be tested for heteroscedasticity. In the regression models, the assumption that the variance of the error term is constant is known as homoscedasticity. If the error terms do not have constant variance, they are said to be heteroscedastic. Errors may increase as the value of an independent increases. Breusch-Pagan / Cook-Weisberg (estat hottest) test is designed to detect any linear form of heteroscedasticity.

The analyses were performed under two different settings depending on the industry effects: one has ignored the industry and treated the whole sample as a unique pool, and the other one has taken into consideration the industry effects by using dummy variables.

Within each of these settings, CCC which is the indicator of working capital management and three profitability indicators mentioned above were run as both dependent and independent variables interchangeably. The test alternatives are shown in the table below.

Table I. Test Alternatives

\begin{tabular}{|l|l|l|}
\hline & Dependent Variable & Independent Variable \\
\hline & GROUP 1 & \\
\hline 1. & Gross Profit Margin & Cash Conversion Cycle - LN Total Assets \\
\hline 2. & Return on Assets & Cash Conversion Cycle - LN Total Assets \\
\hline 3. & EBIT Margin & Cash Conversion Cycle - LN Total Assets \\
\hline & GROUP 2 & \\
\hline 4. & Cash Conversion Cycle & Gross Profit Margin - LN Total Assets \\
\hline 5. & Cash Conversion Cycle & Return on Assets - LN Total Assets \\
\hline 6. & Cash Conversion Cycle & EBIT Margin - LN Total Assets \\
\hline & GROUP 3 & \\
\hline 7. & Gross Profit Margin & Cash Conversion Cycle - LN Total Assets \\
\hline 8. & Return on Assets & Cash Conversion Cycle - LN Total Assets \\
\hline 9. & EBIT Margin & Cash Conversion Cycle - LN Total Assets \\
\hline & GROUP 4 & \\
\hline 10. & Cash Conversion Cycle & Gross Profit Margin - LN Total Assets - Industry Dummy \\
\hline 11. & Cash Conversion Cycle & Return on Assets - LN Total Assets - Industry Dummy \\
\hline 12 & Cash Conversion Cycle & EBIT Margin - LN Total Assets - Industry Dummy \\
\hline
\end{tabular}




\section{Test Results}

\section{I Gross Profit Margin}

Gross profit margin (GPM) is the highest level profitability measure in the income statement. It deducts only cost of goods sold (cogs) from sales. Therefore it measures the success of the company in terms of product or service profitability. In the analyses, GPM was treated both as dependent and independent variables. When it was independent variable, it is controlled for size and industry effects.

\section{i. GPM-dependent; CCC - independent (controlled for size)}

In this alternative, it is tested that whether CCC has a significant effect on GPM. The results are controlled for size by adding natural logarithm of total assets (LN TA) as an independent variable. Among pooled regression, fixed effects and random effects tests, fixed effects test was applied with a robust option for standard errors. The result is significant. The regression equation can be stated as follows:

$$
\mathrm{GPM}=89.162-0.014^{\star} \mathrm{CCC}-3.47^{\star} \mathrm{LN} \mathrm{TA}+\mathrm{u}_{\mathrm{i}}
$$

\section{ii. GPM - dependent; CCC - independent (controlled for size and industry)}

The purpose of this alternative is same with that of the previous one. In addition, industry effects were controlled by adding a dummy variable. Depending on the data, fixed effects is the best method for this alternative and fixed effects method omits dummy variables. As a result, industry dummy variables had no effect on the regression equation and on the results. Regression equation is the same with previous alternative test.

\section{iii. CCC-dependent; GPM - independent (controlled for size)}

In this alternative, the effect of profitability which is measured by GPM on CCC has been examined. The results are controlled for size by adding natural logarithm of total assets (LN TA) as an independent variable. From three regression tests, fixed effects were selected with a robust option. The result is insignificant, overall $\mathrm{p}$ value of the model is higher 0.05 . The regression equation is as follows:

$$
\mathrm{CCC}=612.81-18.17^{\star} \mathrm{GPM}-6.29^{\star} \mathrm{LN} \mathrm{TA}+\mathrm{u}_{\mathrm{i}}
$$

\section{iv. CCC-dependent; GPM - independent (controlled for size and industry)}

In addition to previous case, industry effects were controlled by adding a dummy variable. Similar to the second case, data required to use of fixed effects and since fixed effects method ignores the dummy variables. Addition of industry dummies did not change the results and the regression equation. 


\subsection{Return on Assets}

Return on Assets (ROA) measures the success of the company in exploiting its assets efficiently. It divides net profit by total assets and therefore includes all items of income and expense. In the analyses, ROA was treated both as dependent and independent variables. When it was independent variable, it is controlled for size and industry effects.

\section{i. ROA-dependent; CCC - independent (controlled for size)}

It is tested that CCC has a significant effect on ROA. The results are controlled for size by adding natural logarithm of total assets (LN TA) as an independent variable. Depending on the data, random effects method with robust option was used. The overall $p$ value of the model is lower than 0.05 and the results are significant. The regression equation is as follows:

$$
\mathrm{ROA}=-12.57+0.0003^{*} \mathrm{CCC}+0.74^{\star} \mathrm{LN} \mathrm{TA}+\mathrm{u}_{\mathrm{i}}
$$

\section{ii. ROA -dependent; CCC - independent (controlled for size and industry)}

In addition to the purpose of previous alternative, industry effects are taken into consideration by using dummy variables. The appropriate model was random effects model and in spite of fixed effects model, random effects model does not omit dummy variables. The overall $\mathrm{p}$ value of the model is lower than 0.05 and the result is significant. The regression equation is as follows:

$$
\mathrm{ROA}=-13.506+0.00028^{\star} \mathrm{CCC}+0.77^{\star} \mathrm{LN} \mathrm{TA}+0.45^{\star} \mathrm{D}_{1}-0.57^{\star} \mathrm{D}_{2}+\mathrm{u}_{\mathrm{i}}
$$

\section{iii. CCC-dependent; ROA - independent (controlled for size)}

It is tested whether profitability (ROA) has a significant effect on working capital management (CCC). The results are controlled for size by adding natural logarithm of total assets (LN TA) as an independent variable. The random effects model was the appropriate test for this alternative and the overall $p$ value of the model is lower than 0.05 . The result is significant and the regression equation can be stated as follows:

$$
\mathrm{CCC}=568.82+0.738^{\star} \mathrm{ROA}-24.19^{\star} \mathrm{LN} \mathrm{TA}+\mathrm{u}_{\mathrm{i}}
$$

\section{iv. CCC-dependent; ROA - independent (controlled for size and industry)}

In this alternative, the purpose is the same with previous one, differently, dummy variables are added in order to measure industry effects on the CCC- ROA relationship. The appropriate model is random effects model and the $\mathrm{p}$ value of the model is lower than 0.05 . The result is significant and the regression equation is as follows:

$$
\mathrm{CCC}=477.57+0.629^{\star} \mathrm{ROA}-22.03^{\star} \mathrm{LN} \mathrm{TA}+55.85^{\star} \mathrm{D}_{1}+5.29^{\star} \mathrm{D}_{2}+\mathrm{u}_{\mathrm{i}}
$$




\subsection{EBIT Margin}

EBIT Margin measures the success of the company in its main operating activities. It divides EBIT by net sales and therefore includes all operating income and expense items but excludes nonoperating items. In the analyses, EBIT Margin was treated both as dependent and independent variables. When it was independent variable, it is controlled for size and industry effects.

\section{i. EBITM - dependent; CCC - independent (controlled for size)}

In this alternative, it is tested that whether CCC has a significant effect on EBIT Margin. The results are controlled for size by adding natural logarithm of total assets (LN TA) as an independent variable. Among pooled regression, fixed effects and random effects tests, fixed effects test was applied and results were also robusted. The result is significant. The regression equation can be stated as follows:

$$
\mathrm{EBITM}=84.48-0.029^{\star} \mathrm{CCC}-3.71^{\star} \mathrm{LN} \mathrm{TA}+\mathrm{u}_{\mathrm{i}}
$$

\section{ii. EBITM - dependent; CCC - independent (controlled for size and industry)}

The purpose of this alternative is same with that of the previous one. In addition, industry effects were controlled by adding a dummy variable. Depending on the data, fixed effects is the best method for this alternative and fixed effects method omits dummy variables. As a result, industry dummy variables had no effect on the regression equation and on the results. Regression equation is the same with previous alternative test.

iii. CCC-dependent; EBITM - independent (controlled for size)

In this alternative, the effect of profitability which is measured by EBIT Margin on CCC has been examined. The results are controlled for size by adding natural logarithm of total assets (LN TA) as an independent variable. From three regression tests, fixed effects were selected with a robust option. The result is significant, overall $p$ value of the model is lower than 0.05 . The regression equation is as follows:

$$
\mathrm{CCC}=-114.22-10.007^{\star} \mathrm{EBITM}+17.064^{\star} \mathrm{LN} \mathrm{TA}+\mathrm{u}_{\mathrm{i}}
$$

\section{iv. CCC-dependent; EBITM - independent (controlled for size and industry)}

In addition to previous case, industry effects were controlled by adding a dummy variable. Similar to the second case, data required to use of fixed effects and since fixed effects method ignores the dummy variables. Addition of industry dummies did not change the results and the regression equation. 
Table 2. The Results Of Models In Which Profitability Measures Are Dependent Variables

\begin{tabular}{|c|c|c|c|c|c|c|}
\hline \multirow[b]{3}{*}{ Dependent var. } & \multicolumn{3}{|c|}{ GROUP 1} & \multicolumn{3}{|c|}{ GROUP 3} \\
\hline & Model 1 & Model 2 & Model 3 & Model 7 & Model 8 & Model 9 \\
\hline & GPM & ROA & EBITM & GPM & ROA & EBIT \\
\hline Intercept & $\begin{array}{l}89.162 \\
(0.001)\end{array}$ & $\begin{array}{l}-12.57 \\
(0.000)\end{array}$ & $\begin{array}{c}84.48 \\
(0.012)\end{array}$ & $\begin{array}{l}89.162 \\
(0.001)\end{array}$ & $\begin{array}{l}-13.506 \\
(0.000)\end{array}$ & $\begin{array}{c}84.48 \\
(0.012)\end{array}$ \\
\hline $\mathrm{CCC}$ & $\begin{array}{l}-0.014 \\
(0.000)\end{array}$ & $\begin{array}{l}0.0003 \\
(0.388)\end{array}$ & $\begin{array}{l}-0.029 \\
(0.000)\end{array}$ & $\begin{array}{l}-0.014 \\
(0.000)\end{array}$ & $\begin{array}{c}0.00028 \\
(0.428)\end{array}$ & $\begin{array}{c}-0.029 \\
(0.000)\end{array}$ \\
\hline LN TA & $\begin{array}{l}-3.47 \\
(0.015)\end{array}$ & $\begin{array}{c}0.74 \\
(0.000)\end{array}$ & $\begin{array}{l}-3.71 \\
(0.033)\end{array}$ & $\begin{array}{l}-3.47 \\
(0.015)\end{array}$ & $\begin{array}{c}0.77 \\
(0.000)\end{array}$ & $\begin{array}{l}-3.71 \\
(0.033)\end{array}$ \\
\hline $\begin{array}{l}\text { Ind. dummy } \\
\text { (D1) }\end{array}$ & na & na & na & omitted & $\begin{array}{c}0.45 \\
(0.790)\end{array}$ & omitted \\
\hline $\begin{array}{l}\text { Ind. dummy } \\
\text { (D2) }\end{array}$ & na & na & na & omitted & $\begin{array}{l}-0.57 \\
(0.767)\end{array}$ & omitted \\
\hline $\mathrm{R} 2$ & 0.2766 & 0.11 & 0.3041 & 0.2766 & 0.1188 & 0.3041 \\
\hline $\begin{array}{c}\text { F-Test } \\
\star \text { Wald Chi }^{2}\end{array}$ & $\begin{array}{c}9.5 \\
(0.0001)^{\star *}\end{array}$ & $\begin{array}{c}{ }^{\star} 20.28 \\
(0.0000)^{\star *}\end{array}$ & $\begin{array}{c}32.26 \\
(0.000)^{* *}\end{array}$ & $\begin{array}{c}9.5 \\
(0.0001)^{\star *}\end{array}$ & $\begin{array}{c}{ }^{\star} 21.69 \\
(0.0002)^{* *}\end{array}$ & $\begin{array}{c}32.26 \\
(0.000)^{* *}\end{array}$ \\
\hline Observations & 860 & 860 & 860 & 860 & 860 & 860 \\
\hline
\end{tabular}

Table 3. The Results Of Models In Which Cash Conversion Cycle Is Dependent Variable

\begin{tabular}{|c|c|c|c|c|c|c|}
\hline \multirow[b]{3}{*}{ Dependent Var. } & \multicolumn{3}{|c|}{ GROUP 2} & \multicolumn{3}{|c|}{ GROUP 4} \\
\hline & Model 4 & Model 5 & Model 6 & Model 10 & Model 11 & Model 12 \\
\hline & CCC & $\mathrm{CCC}$ & $\mathrm{CCC}$ & $\mathrm{CCC}$ & $\mathrm{CCC}$ & CCC \\
\hline Intercept & 612.81 & 568.82 & -114.22 & 612.81 & 477.57 & -114.22 \\
\hline mercept & $(0.464)$ & $(0.000)$ & $(0.846)$ & $(0.464)$ & $(0.001)$ & $(0.846)$ \\
\hline GPM & $\begin{array}{l}-18.17 \\
(0.094)\end{array}$ & - & - & $\begin{array}{l}-18.17 \\
(0.094)\end{array}$ & - & - \\
\hline ROA & - & $\begin{array}{c}0.738 \\
(0.625)\end{array}$ & - & - & $\begin{array}{c}0.629 \\
(0.679)\end{array}$ & - \\
\hline EBITM & - & - & $\begin{array}{l}-10.007 \\
(0.000)\end{array}$ & - & - & $\begin{array}{c}-10.007 \\
(0.000)\end{array}$ \\
\hline LN TA & $\begin{array}{c}-6.29 \\
(0.867)\end{array}$ & $\begin{array}{l}-24.19 \\
(0.000)\end{array}$ & $\begin{array}{l}17.064 \\
(0.585)\end{array}$ & $\begin{array}{c}-6.29 \\
(0.867)\end{array}$ & $\begin{array}{l}-22.03 \\
(0.001)\end{array}$ & $\begin{array}{l}17.064 \\
(0.585)\end{array}$ \\
\hline Ind. dummy (D1) & na & na & na & omitted & $\begin{array}{c}55.85 \\
(0.153)\end{array}$ & omitted \\
\hline Ind. dummy (D2) & na & na & na & omitted & $\begin{array}{c}5.29 \\
(0.898)\end{array}$ & omitted \\
\hline $\mathrm{R} 2$ & 0.2665 & 0.0622 & 0.3012 & 0.2665 & 0.0703 & 0.3012 \\
\hline F-Test & 1.56 & *14.16 & 46.68 & 1.56 & ^17.79 & 46.68 \\
\hline${ }^{*}$ Wald $\mathrm{Chi}^{2}$ & $(0.2129)$ & $(0.0008)^{\star *}$ & $(0.000)^{\star *}$ & $(0.2129)$ & $(0.0014)^{\star *}$ & $(0.000)^{\star \star}$ \\
\hline Observations & 860 & 860 & 860 & 860 & 860 & 860 \\
\hline
\end{tabular}

Significance levels are shown in parentheses. In models which used Fixed Effects, dummy variables are omitted . Depending on the model, F-test or Wald $\left.\mathrm{chi}^{2}{ }^{*}\right)$ test are reported, and they show overall significance of each model.

**: significant at $95 \%$ confidence level. 


\section{Conclusion}

In order to evaluate the success of financial management, short-term decisions, and more specifically, working capital policies must be taken into consideration as well as long-term decisions such as capital budgeting, capital structure etc. Working capital management affect and also is affected by the profitability of the company. The objective of working capital management is to keep optimal levels of items of cash, receivables, inventory and payables. In this sense, the most commonly used measure is cash conversion cycle (CCC). The shorter the CCC, the more successful the working capital policy of the company. The other side of the relationship is profitability. In this sense, there are also several indicators depending on the coverage of the measure. Gross profit margin (GPM), EBIT margin (EBITM) and Return on Assets margin (ROA) are mostly accepted in the literature and each of them show different level of profitability in the income statement.

In this article, the relationship between profitability and working capital management were examined reciprocally. More specifically, by using a panel data of five years and 172 companies, regressions were run in four groups. In the first group, the profitability measures were dependent variable, and CCC was independent variable. In the second group, CCC was dependent variable and the profitability measures were independent variable. In the third group, the relationship of the first group was tested by including dummy variables for industry effects. In the fourth group, the relationship of the second group was tested by including dummy variables for industry effects. In each of the groups mentioned, three profitability measures were tested separately together with CCC. As a result, there were twelve alternatives.

Most of the alternatives had generated significant results except the two. The alternatives which have given insignificant results were CCC-dependent, GPM-independent, excluding and including industry effects. In general, the dummy variables for industry effects did not change the results.

When measured by ROA and EBITM, it can be concluded that working capital management has a significant effect on the profitability of the company and also it is significantly affected by the profitability. In terms of GPM, the effect of GPM level on CCC is not significant, however the reverse is not true. The level GPM is affected by working capital policy, and namely CCC.

To conclude the objective and result of this article, it can be stated that there is a strong interrelationship between profitability and working capital management policy and practices of companies. The implication of this result is that companies must shorten their cash conversion cycles by focusing on each of the components and such a policy will help increase profitability. Secondly, the policies and practices which benefit the level of profitability will help increase the quality of working capital components. 


\section{References}

BRIGHAM, Eugene F., and HOUSTON,Joel F. (2009), “Fundamentals of Financial Management”, SouthWestern Publishing, pp.492-494.

DELOOF, Marc (2003), “Does working capital management affect profitability of Belgian firms?", Journal of Business Finance \& Accounting, Vol. 30 Nos 3/4, pp. 573-88.

ENQVIST, Julius, GRAHAM, Michael and NIKKINEN, Jussi (2014), “The impact of working capital management on firm profitability in different business cycles: Evidence from Finland", Research in International Business and Finance 32, pp.36-49

GARCIA-TERUEL, Pedro Juan and MARTINEZ-SOLANA, Pedro, (2007),"Effects of working capital management on SME profitability", International Journal of Managerial Finance, Vol. 3 Iss 2 pp. $164-177$

GENTRY, J.A., VAIDYANATHAN, R., LEE, R. and WAI, H. (1990), "A weighted cash conversion cycle",Financial Management, Vol. 19 No. 1, pp. 90-9.

GILL, Amarjit, BIGER, Nahum and MATHUR, Neil, 2010, “The relationship between working capital management and profitability: evidence from the United States", Business Economics J. 10, 1-9.

GITMAN, L.J. (1974), “Estimating corporate liquidity requirements: a simplified approach”, The Financial Review, Vol. 9, pp. 79-88.

JOSE, Manuel L., LANCASTER, Carol and STEVENS, Jerry L. (1996), "Corporate return and cash conversion cycle", Journal of Economics and Finance, Vol. 20, pp. 33-46.

LAZARIDIS, Ioannis and TRYFONIDIS, Dimitrios 2006. "Relationship between working capital management and profitability of listed companies onthe Athens Stock Exchange”. J. Financial Management Anal. 19 (1), 26-35.

ÖHMAN,Darush Yazdanfar Peter (2014),'The impact of cash conversion cycle on firm profitability "International Journal of Managerial Finance, Vol. 10 Iss 4 pp. 442 - 452

PADACHI, Kesseven (2006), “Trends in working capital management and its impact on firms' performance: an analysis of Mauritian small manufacturing firms", International Review of Business Research Papers, Vol. 2 No. 2, pp. 45-58.

RICHARDS, Verlyn D. and LAUGHLIN, Eugene J. (1980), "A cash conversion cycle approach to liquidity analysis", Financial Management, Vol. 9 No. 1, pp. 32-38.

SHIN, Hyun Han and SOENEN, Luc (1998), "Efficiency of working capital management and corporate profitability”, Financial Practice \& Education, Vol. 8 No. 2, pp. 39-45.

SMITH, Keith (1980), "Profitability versus liquidity tradeoffs in working capital management", in Smith, K.V. (Ed.), Readings on the Management of Working Capital, West Publishing Company, St Paul, MN, pp. 549-62.

SOENEN, Luc (1993), "Cash conversion cycle and corporate profitability", Journal of Cash Management, Vol. 13 No. 4, pp. 53-57.

UKAEGBU, Ben 2014, “The significance of working capital management in determining firm profitability: evidence from developing economies in Africa", Research in International Business and Finance 31, pp. 1-16.

WANG, Yung Jang (2002), "Liquidity management, operating performance, and corporate value: evidence from Japan and Taiwan”, Journal of Multinational Financial Management, Vol. 12 No. 2, pp. 159-169.

WOOLDRIDGE, Jeffrey M., (2002), “Introductory Econometrics, A Modern Approach" 2nd Edition, Thomson Learning, pp.430-432 